\title{
BIOLOGICAL ACTIVITIES OF THIONATED THYROTROPIN-RELEASING HORMONE ANALOGS
}

\author{
Leszek Lankiewicz, ${ }^{*}$ Cyril Y. Bowers, ${ }^{* *}$ G.A. Reynolds, ${ }^{* *}$ \\ Virender Labroo, ${ }^{* * *}+$ Louis A. Cohen, ${ }^{* * *}$ Stefan Vonhof, ${ }^{* * * *}$ \\ Anna-Leena Sirén, ${ }^{* * * *}$ and Arno F. Spatola $* \ddagger$
}

*Department of Chemistry, University of Louisville, Louisville, KY 40292

**School of Medicine, Tulane University, New Orleans, LA 70112

${ }^{* * *}$ National Institutes of Health, Bldg. 8A, Room, B1A-09, Bethesda, MD 20892

*****Department of Neurology, Uniformed Services

University of the Health Sciences, 4301 Jones Bridge Road, Bethesda, MD 20814

Received February 28, 1992

SUMMARY: Analogs of thyrotropin-releasing hormone (Glp-His-Pro- $\mathrm{NH}_{2}$, TRH) have been prepared which contain thioamide moieties in the pyroglutamic acid ring, the carboxyamide proline terminus, and in both positions (dithio). These compounds have been tested for TSH-releasing activities (in vitro and in vivo), and for binding to TRH receptors in rat pituitary and cortex. The monothionated analogs showed no significant differences in TSH-releasing potency from TRH either in vitro or in vivo. However, with two thioamide replacements the potency decreases about $50 \%$. Significantly, in terms of receptor selectivity, thionation has resulted in differentiation between brain receptors (pituitary and cortex). The Pro $\psi\left[\mathrm{CSNH}_{2}\right]$ and dithio analogs were more selective (higher affinity to pituitary receptors) than the parent hormone, while the analog containing a thioamide replacement in the pyroglutamyl ring had lower affinity and was not selective. These results suggest that the subtle exchange of sulphur for oxygen can have an important impact on both receptor selectivity and affinity within a biologically active peptide.

Design of new analogs of naturally occurring peptides through modification of the peptide backbone has become increasingly important (1-3). Peptide backbone modifications are used to obtain more active analogs, to achieve enzymatic stability, to improve or change receptor selectivity, and to change transport properties. The complex changes in the biological profile of analogs can be rationally analyzed and understood especially when the modified peptide adopts a conformation similar to that of the non-modified peptide (4).

$\dagger$ Present address: ZymoGenetics, 4225 Roosevelt Way, Seattle, WA 98105. $¥$ Address inquiries to this author. 
One of the most subtle and conservative variations within peptides is the thioamide surrogate, $\psi[\mathrm{CSNH}]$, in which the amide oxygen has been replaced by sulfur. Various physical studies (5-8) indicate that thioamides are highly isosteric with the amides (mainly the $\mathrm{Z}$ planar configuration), except that incorporation of the sulfur changes the hydrogen-bonding properties (9). Thus, the $\mathrm{NH}$ in the thioamide is a stronger donor and the $\mathrm{C}=\mathrm{S}$ is a weaker acceptor than the $\mathrm{NH}$ and the $\mathrm{C}=\mathrm{O}$ in the amides, respectively.

In spite of the physical compatibilities, biological activities of thiopeptides are often unpredictable. The C-terminal thioamide analog of oxytocin ([Gly $\left.\psi\left[\mathrm{CSNH}_{2}\right] 9\right] \mathrm{OT}$ ), displayed $6 \%$ oxytoxic and $1.5 \%$ AVD activity compared to oxytocin (10). Also the C-terminal thioamide analog of growth hormonereleasing peptide (11), the leucine enkephalin thionated in the 1-2 position (12), and the thio analog of dermorphin (13) have proven less active than their parent peptide, whereas the C-terminal thioamide analog of thyrotropin-releasing hormone is almost equipotent with TRH in terms of its TSH-releasing activity (14).

On the other hand, thionation of the 2-3 bond in leucine enkephalin resulted in a more active and selective (higher affinity to $\delta$ than to $\mu$ opioid receptors) analog than the parent peptide (12). We have also reported (15) the biological activity of multithionated cyclic analogs of enkephalin based on the SchillerDiMaio (16) structure, H-Tyr-cyclo(Ne-D-Lys-Gly-Phe-Leu). As the number of sulfurs increased, biological activities decreased, but the compounds displayed increasing $\delta$ selectivity.

Because of the interesting influence of sulfur(s) on the receptor selectivity in the series of cyclic enkephalins (15) and the high activity of previously synthesized $\left[\right.$ Prow $\left.\left[\mathrm{CSNH}_{2}\right]^{3}\right] \mathrm{TRH}(14)$, we decided to examine the effect of the thioamide moiety in a series of new TRH analogs $(17,18)$. In this paper, we describe the synthesis and biological activity profiles of the thionated analogs of thyrotropin-releasing hormone (I), containing the thioamide in the pyroglutamic acid ring, carboxyamide proline terminus, and in both positions (dithio analog IV) as shown in Figure 1.

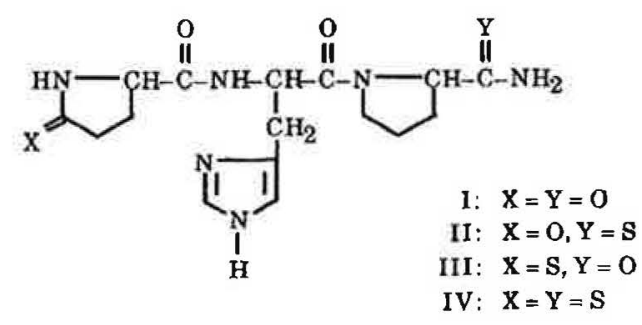

Figure 1. Thionated analogs of TRH. 


\section{MATERIALS AND METHODS}

All compounds were synthesized using solution phase methods. The protected peptides Glp-His(DNP)-Prow $\left[\mathrm{CSNH}_{2}\right]$, TFA $\cdot \mathrm{His}(\mathrm{DNP})-\operatorname{Pro}-\mathrm{NH}_{2}$, and TFA - His (DNP)-Prow [CSNH 2$]$ were synthesized using routes analogous to those previously reported (14).

Top-His-Pro- $\mathrm{NH}_{2}$ (III) (Top = thiopyroglutamic acid) and Top-His-Proy [CSNH ${ }_{2}$ ] (IV) were prepared by two methods beginning with thionation of Glp-OtBu and Glp-OTcp (Tcp = 2,4,5-trichlorophenyl) by Lawesson's Reagent (LR) in THF at $25^{\circ} \mathrm{C}$ to afford Top-OtBu and Top-OTep in $94 \%$ and $74 \%$ yield, respectively. In the first method, following deprotection with $4 \mathrm{~N} \mathrm{HCl} /$ dioxane, TopOH was coupled to TFA $\cdot \mathrm{His}(\mathrm{DNP})-\mathrm{Pro}_{-} \mathrm{NH}_{2}$ and TFA -His(DNP)-Prow[CSNH ${ }_{2}$ ] with 1-ethyl-3-(3-dimethylaminopropyl)carbodiimide (EDC) and 1-hydroxybenzotriazole (HOBt) in DMF to yield after workup Top-His(DNP)-Pro- $\mathrm{NH}_{2}$ and Top-His(DNP)-Prow $\left[\mathrm{CSNH}_{2}\right]$ in $76 \%$ and $71 \%$ yields, respectively.

In the second method, Top-OTcp was coupled to TFA $-\mathrm{His}(\mathrm{DNP})-\mathrm{Pro}-\mathrm{NH}_{2}$, and TFA $\cdot$ His(DNP)-Pro $\psi\left[\mathrm{CSNH}_{2}\right]$ in DMF in the presence of HOBt to obtain Top-His(DNP)-Pro-NH $\mathrm{NH}_{2}$ and Top-His(DNP)-Prow[CSNH $\left.{ }_{2}\right]$ in $86 \%$ and $80 \%$ yields, respectively.

Cleavage of the DNP protecting groups by mercaptoethanol in DMF generated crude Glp-His-Pro $\psi\left[\mathrm{CSNH}_{2}\right]$ (II), Top-His-Pro- $\mathrm{NH}_{2}$ (III) and Top-His-Pro $\psi\left[\mathrm{CSNH}_{2}\right]$ (IV) were purified by normal phase column chromatography followed by gel filtration on Sephadex G-10.

Final purification was accomplished by reversed phase chromatography on a Vydac $\mathrm{C}-18$ column $(2.5 \times 25 \mathrm{~cm})$ using a solution of $\mathrm{CH}_{3} \mathrm{CN}$ in $0.05 \%$ TFA in $\mathrm{H}_{2} \mathrm{O}$ (5\% for II, $4 \%$ for III, and $9 \%$ for IV) at a flow rate of $3.5 \mathrm{ml} / \mathrm{min}$.

Purity of the analogs was assessed with two separate TLC (Kiesegel 60) systems: (A) $\mathrm{CHCl}_{3} / \mathrm{MeOH}, 1: 3 ;$ (B) n-BuOH/AcOH/H $/ 2$ O/AcOEt, $1: 1: 1: 1$, and by analytical reversed phase HPLC (a linear gradient of $5-35 \%$ of $\mathrm{CH}_{3} \mathrm{CN}$ in $0.05 \%$ TFA over $30 \mathrm{~min}$ at a flow rate of $1.0 \mathrm{ml} / \mathrm{min}$, column: Vydac $4.6 \times 250 \mathrm{~mm}, \mathrm{C}-18$ ).

The peptides were further characterized by amino acid analysis and fast atom bombardment mass spectrometry (FABMS).

Glp-His-Prow[CSNH 2 (II): TLC Rf: 0.47 (A); 0.39 (B). Analytical RP-HPLC $t_{R}$ : 9.99 min. Amino acid analysis: Glu 1.06; His 1.05, Pro 1.00. FABMS: 379 (calc. $\mathrm{M}+\mathrm{H}, 379)$.

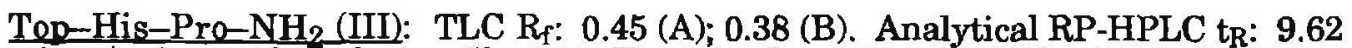
min. Amino acid analysis: Glu 0.98, His 1.19, Pro 1.00. FABMS: 379 (calc. $\mathrm{M}^{+}+$ $\mathrm{H}, 379$ ).

Top-His-Prow[CSNH 2 ] (IV): TLC Rf: 0.51 (A); 0.43 (B). Analytical RP-HPLC tR: $14.59 \mathrm{~min}$. Amino acid analysis: Glu 0.97 , His 1.08, Pro 1.00. FABMS: 395 (calc. $\left.\mathrm{M}^{+}+\mathrm{H}, 395\right)$.

In vitro assays: Adult female rats were sacrificed by decapitation and anterior pituitaries removed as quickly as possible, minced, and placed in an Erlenmeyer flask containing trypsin in Gey's buffer at $37^{\circ} \mathrm{C}$ with $5 \% \mathrm{CO}_{2}$ for $35 \mathrm{~min}$. Cells were washed and suspended in deoxyribonuclease I and gassed for $4 \mathrm{~min}$ more. Cells were washed and triturated with a lima bean inhibitor, centrifuged, suspended in DMEM and plated at $2.6 \times 10^{5} \mathrm{cells} / \mathrm{ml}$. All peptides were dissolved in water, diluted in $0.1 \%$ gelatin water and added to the wells in a $30 \mu \mathrm{l}$ volume. Each value is the mean of $3 \pm$ sem. 
In vive assays: Female CD-1 strain rats about 26 days of age were used for these studies. Rats were maintained at a constant temperature $\left(25^{\circ} \mathrm{C}\right)$ on a 14 -h light, 10-h dark cycle and food and water were available ad libitum. All peptides were dissolved in water $(1: 1)$, diluted in $0.1 \%$ gelatin saline and administered sc to conscious rats. Trunk blood was collected by decapitation at +20 min and +40 min after peptide administration. Each value is the mean of $6 \pm \mathrm{sem}$.

The RIA was performed with reagents distributed by the NIDDK program. The TSH levels are recorded in terms of the RP-2 reference standard.

Recentor binding assays. Fresh tissue samples of pituitary and cortex were obtained from male Sprague-Dawley rats. Radioreceptor assays were performed using [3H][3-Me-His 2$]$ TRH (NEN) as the radioligand (19). Briefly, tissue samples were homogenized (Brinkman Polytron) in 25 vol. of $100 \mathrm{mM}$ sodium phosphate buffer. After centrifugation at $39000 \mathrm{~g}$ for $30 \mathrm{~min}$, the pellets were resuspended in ice-cold buffer containing $177 \mu \mathrm{M}$ bacitracin to a concentration of 50 (pituitary) or 100 (cortex) $\mathrm{mg} / \mathrm{ml}$. The tissue resuspensions were incubated with

$[3 \mathrm{H}]\left[3-\mathrm{Me}-\mathrm{His}^{2}\right] \mathrm{TRH}$ and increasing analog concentrations at 4 to $6^{\circ} \mathrm{C}$ for $2.5 \mathrm{~h}$. Nonspecific binding was determined in the presence of $10 \mu \mathrm{M}$ TRH. The incubation was terminated by vacuum filtration through Whatman GF/B glass filters by means of a 48 well cell harvester (Brandel), followed by 3 rinses of $4 \mathrm{ml}$ of ice-cold $0.9 \%$ sodium chloride solution each. Filters were placed in glass scintillation vials, immersed in scintillation fluid (Beckman ReadySolv HP) and bound radioactivity counted on the following day. Inhibition constants $\mathrm{K}_{\mathrm{i}}$ were determined according to Cheng and Prusoff (20) using the radioligand binding analysis program LIGAND (Elsevier-Biosoft).

\section{RESUTTS AND DISCUSSION}

The results of the in vitro biological activities are reported in Table 1. All four of the tripeptides significantly released TSH in vitro. Analog III in which the carbonyl oxygen of the pyroglutamyl ring was substituted by sulfur and analog II in which the carbonyl oxygen of the carboxyamide at the $\mathrm{C}$ terminus was substituted by sulfur had essentially the same TSH-releasing activity as the parent peptide TRH. Analog IV, with dithio substitutions at the above sites, was slightly less active than TRH, II, or III at all three dosages.

In the in vivo assay (Table 2) the results again demonstrate that all four of the tripeptides significantly released TSH. Essentially the same relative degree of

TABLE 1. Biological activities in vitro of thionated analogs of thyrotropin-releasing hormone

\begin{tabular}{|c|c|c|c|c|}
\hline \multirow{2}{*}{\multicolumn{2}{|c|}{ Structure }} & \multicolumn{3}{|c|}{ rTSH $\mathrm{ng} / \mathrm{ml} \mathrm{ISEM}$ at dose } \\
\hline & & $3 \mathrm{ng}$ & $10 \mathrm{ng}$ & $30 \mathrm{ng}$ \\
\hline I & Glp-His-Pro-NH 2 (TRH) & $5.0 \pm 0.3$ & $5.0 \pm 0.5$ & $5.3 \pm 0.1$ \\
\hline II & Glp-His-Pro $\left[\mathrm{CSNH}_{2}\right]$ & $3.9 \pm 0.2$ & $5.0 \pm 0$ & $3.9 \pm 0.8$ \\
\hline III & Top-His-Pro-NH 2 & $3.9 \pm 0.1$ & $5.6 \pm 0$ & $6.0 \pm 0.1$ \\
\hline IV & Top-His-Prow $\left[\mathrm{CSNH}_{2}\right]$ & $3.0 \pm 0.2$ & $4.0 \pm 0.3$ & $3.0 \pm 0.8$ \\
\hline
\end{tabular}

a baseline $1.6 \pm 0$ 
TABLE 2. Biological activities in vivo of analogs of thyrotropinreleasing hormone

\begin{tabular}{|c|c|c|c|c|c|c|}
\hline & \multirow[b]{2}{*}{ Structure } & \multicolumn{4}{|c|}{ rTSH $n g / m u S E M$ at dose } & \multirow{2}{*}{$\begin{array}{c}(40 \mathrm{~min})^{\mathrm{b}} \\
1 \mu \mathrm{g}\end{array}$} \\
\hline & & $0.1 \mu \mathrm{g}$ & $0.3 \mu \mathrm{g}$ & $1.0 \mu \mathrm{g}$ & $3 \mu \mathrm{g}$ & \\
\hline I & Glp-His-Pro-NH 2 (TRH) & $11+2$ & $20+2$ & $20 \pm 1$ & $30 \pm 3$ & $9+2$ \\
\hline II & Glp-His-Pто $\psi\left[\mathrm{CSNH}_{2}\right]$ & $13 \pm 1$ & $16+2$ & $20 \pm 3$ & $21+3$ & $7 \pm 1$ \\
\hline III & Top-His-Pro- $\mathrm{NH}_{2}$ & $13+2$ & $21+2$ & $24 \pm 1$ & $25 \pm 3$ & $8+1$ \\
\hline IV & Top-His-Pro $\psi\left[\mathrm{CSNH}_{2}\right]$ & $5 \pm 2$ & $9 \pm 2$ & $20+2$ & $22+1$ & $4+2$ \\
\hline
\end{tabular}

- Female rats: 26 days old; sacrificed 20 min after injection; or b 40 min after injection; $n=6$; baseline $=0.7 \pm 0.2$

TSH-releasing activity for each peptide was found in vivo and in vitro. When the studies were performed at $+20 \mathrm{~min}$ after injection of the peptide, the TSHreleasing activities of analogs II and III were nearly the same as that of TRH (I). Although analog IV definitely released TSH, it was less active than II, III, or I. When the studies were performed at $+40 \mathrm{~min}$, the same relative activities were observed.

We next examined the binding of our analogs toward pituitary and cortical receptors for TRH (Table 3). The order of decreasing pituitary receptor affinities was analog II, TRH and IV, and III, while the values for the CNS cortical receptor affinity were TRH > analogs II and III > IV. Thus, of the four peptides, the binding of analog II was greatest on pituitary receptor and TRH greatest on the cortical receptor. Furthermore, comparison of the $K_{i} c / K_{i} P$ ratios of these four peptides indicates that thionated TRH analogs have been developed that have different relative affinities than TRH for the cortex and pituitary receptors. For example, the $\mathrm{K}_{\mathrm{i}} \mathrm{C} / \mathrm{K}_{\mathrm{i}} \mathrm{P}$ ratio results of $\mathrm{TRH}$ and analog III were the same while analogs II and IV were 11- and 15-fold higher than TRH. Even though analog IV and TRH bound equally to the pituitary receptor, analog $I V$ binding to the cortex receptor was 20 -fold less than TRH. In comparison to TRH, analog II binding to

TABLE 3. Binding assays of thionated analogs of thyrotropinreleasing hormonea

\begin{tabular}{|c|c|c|c|c|c|c|}
\hline & & PIT & UTTARY & $\mathrm{COR}$ & & \\
\hline & Structure & $\mathbf{K}_{\mathrm{i}} \mathbf{P}(\mathrm{nM})$ & $\begin{array}{l}\text { Relative } \\
\text { Potency }\end{array}$ & $\mathbf{K}_{\mathrm{i}} \mathbf{C}(\mathbf{n} \mathbf{M})$ & $\begin{array}{l}\text { Relative } \\
\text { Potency }\end{array}$ & $\mathbf{K}_{\mathbf{i}} \mathbf{C} / \mathbf{K}_{\mathbf{i}} \mathbf{P}$ \\
\hline I & Glp-His-Pro-NH ${ }_{2}$ (TRH) & $24.1+14.2$ & 1.0 & $26.1 \pm 4.5$ & 1.0 & 1.08 \\
\hline II & Glp-His-Prow[CSNH $\left.{ }_{2}\right]$ & $8.0 \pm 0.2$ & 3.01 & $93.1+16.5$ & 0.28 & 11.64 \\
\hline III & Top-His-Pro-NH ${ }_{2}$ & $85.4 \pm 17.8$ & 0.23 & $86.1+6.3$ & 0.30 & 1.01 \\
\hline IV & Top-His Prow $\left[\mathrm{CSNH}_{2}\right]$ & $31.9 \pm 2.9$ & 0.76 & $501 \pm 173$ & 0.05 & 15.71 \\
\hline
\end{tabular}

a $\left.\left[{ }^{3} \mathrm{H}\right]-3-\mathrm{Me}-\mathrm{His}^{2}\right]$ TRH was used as the radioligand. 
the pituitary receptor was greater and less on the cortex while the binding of analog III and TRH was nearly the same on both receptors.

The biological profiles of the new thionated analogs of TRH thus provide a further example of selectivity changes that may be induced through modification of the peptide backbone. Substitution of the one oxygen at the C- or N-terminus produced analogs (II and III) that were essentially equipotent in TSH release with the natural hormone both in vitro and in vivo. The in vivo biological activity of the Prow[CSNH $\left.{ }_{2}\right]$ analog (II) is similar to that reported by Kruszynski et al. (14). However, when a sulfur substitution was made at both the $\mathrm{N}$ - and $\mathrm{C}$-termini, the TSH-releasing activity was less, particularly at the lower dosages. These results are especially interesting when compared with the lipophilicity of the analogs, which was determined as a function of their HPLC retention times. The monothionated analog (III), with high pituitary receptor binding activity, has the shortest retention time $\left(t_{R}=9.62 \mathrm{~min}\right)$. The Pro $\psi\left[\mathrm{CSNH}_{2}\right]$ analog (II) is only a little more hydrophobic $\left(t_{R}=9.99 \mathrm{~min}\right)$. The most hydrophobic peptide was the dithionated analog IV ( $t_{R}=14.59 \mathrm{~min}$ ), which also happens to show the greatest binding selectivity. The retention time of TRH is $5.17 \mathrm{~min}$.

TRH has multiple biological effects at various anatomical sites which may be mediated via different TRH receptor subtypes (22-25). Previously, we have observed that backbone thionation of enkephalins yielded receptor-selective analogs $(12,15)$.

Comparison of the pituitary receptor-binding affinity and TSH-releasing activity results of analogs II and III were particularly surprising. The pituitary affinity of analog III was low and that of analog II was high and yet both released an amount of TSH equal to that of TRH. This result may indicate that the $\mathrm{C}=\mathrm{S} \mathrm{N}$ terminal substitution of analog III decreased binding while increasing the efficiency and effectiveness of the activation mechanism which mediates TSH from the pituitary thyrotrophes. Alternatively, this factor could be the result of altered stability of the thio analog toward enzymatic degradation (26).

Parenthetically, the $\mathrm{C}=\mathrm{S} \mathrm{C}$-terminal substitution of analog II increased binding while not significantly affecting the activation mechanism. As yet, the molecular details of how TRH activates the receptor have not been elucidated. The paradoxical dual effects of analogs II and III on binding and activation seemingly indicate the more global nature of this problem and the difficulty of separating the components of the TRH molecule that are selectively responsible for these individual effects. The affinity/releasing activity of analog IV with $\mathrm{C}=\mathrm{S}$ substitutions at both the $\mathrm{N}$ - and C-terminus appears to result in some type of a hybrid effect of analogs II and III. The reduction in binding from the $\mathrm{N}$-terminal substitution is compensated to a large extent by enhanced binding via C-terminal substitution, resulting in essentially similar binding of TRH and analog IV. This hybrid effect could be due in part to the considerably greater hydrophobicity of analog IV than II or III. 
The effects observed through $\mathrm{C}=\mathrm{S}$ substitution may help to guide or impart new insights into the chemical mechanisms involved in TRH receptor binding and activation. For example, the effects of thionation of the carbonyl-carbon at the C-terminal amide may be induced by stronger hydrogen bonding via the $\mathrm{NH}_{2}$ group while the thionation of the carbonyl carbon of the pyroglutamyl ring may decrease hydrogen bonding via reduced acceptor properties of the $\mathrm{C}=\mathrm{S}$ group. Just how the $\mathrm{C}=\mathrm{S} \mathrm{C}$-terminal substitution might increase activation and decrease binding is not readily apparent. However, this may indicate the importance of the $\mathrm{N}$-terminus for TRH activation. The increased donor capacity of the thioamide NH compared to the parent amide may rationalize this behavior. Alternatively, a "pocket" for the $\mathrm{C}=\mathrm{O}$ group on the pituitary receptor may accommodate the $\mathrm{C}=\mathrm{O}$ more readily than the $\mathrm{C}=\mathrm{S}$ group because of the larger size of the $\mathrm{S}$ than the $\mathrm{O}$ atom; however, once the thioamide group is in the "pocket" its altered hydrogen bonding is more effective and efficient in activating the receptor than the amide.

Apparently, neither of the hydrogen bonding changes induced by the $\mathrm{C}=\mathrm{S}$ substitutions favors binding of the analogs to the cortical receptor. Whether cortical receptor affinities of future TRH analogs might be selectively augmented by increasing hydrogen bonding at the $\mathrm{N}$-terminus of TRH and/or by decreasing hydrogen bonding at the $\mathrm{C}$-terminus will warrant consideration.

Overall, the results of these studies provide interesting contributions to understanding the influence of the thioamide bond replacement on the activity and selectivity of biologically active peptides. More specifically, it has been shown that thionation of TRH leads to preferential binding to receptors in different tissues. This may prove useful for further defining the role and chemical mechanisms of TRH receptor binding and activation in various tissues.

\section{Acknowledgments}

The experiments reported herein were conducted according to the principles set forth in the "Guide for Care and Use of Laboratory Animals," Institute of Laboratory Animal Resources, National Research Council (DHEW Publication No. NIH 85-23, 1985).

\section{REFERENCES}

1. Spatola, A.F. (1983) in Chemistry and Biochemistry of Amino Acids, Peptides, and Proteins (B. Weinstein, ed.) Vol. 7, pp. 267-357, Marcel Dekker, New York.

2. Davies, J. S. (1990) in Amino Acids and Peptides (J. H. Jones, ed.) Vol. 21, pp. 129-137, The Royal Society of Chemistry, Cambridge.

3. Davies, J. S. (1991) in Amino Acids and Peptides (J. H. Jones, ed.) Vol. 22, pp. 145-156, The Royal Society of Chemistry, Cambridge.

4. Aubry, A., Boussard, G., Cung, M. T. Marraud, M., Vitoux, B. (1988) J. Chim. Phys., 85, 345.

5. Sherman, D. B., Spatola, A. F. (1990) J. Am. Chem. Soc., 112, 433. 
6. Kajtar, M., Hollosi, M., Kajtar, T., Majer, Zs., Kover, K. E. (1986) Tetrahedron, 42, 3931.

7. Hollosi, M., Majer, Zs., Zewdu, M., Ruft, F., Kajtar, M., Kover, K. E. (1988) Tetrahedron, 44, 195.

8. Guthrie, D. J. S., Williams, C. H., Elmore, D. T. (1986) Int. J. Peptide Protein Res., 28, 208.

9. Dudek, E. P., Dudek, G. J. (1967) J. Org. Chem., 32, 823.

10. Jones, W. C., Jr., Nestor, J. J., Jr., du Vigneaud, V. J. (1973) J. Am. Chem. Soc., 95, 5677.

11. Majer, Zs., Zewdu, M., Hollosi, M., Seprodi, J., Vadesz, Zs., Teplan, I. (1988) Biochem. Biophys. Res. Commun., 150, 1017.

12. Clausen, K., Spatola, A. F., Lemieux, C., Schiller, P. W., Lawesson, S.-O. (1984) Biochem. Biophys. Res. Commun., 120, 305.

13. Salvadori, S., Manastoni, M., Balboni, G., Tomatis, R., Sarto, G. (1984) Il Farmaco Ed. Sc., 39, 216.

14. Kruszynski, M., Kupryszewski, G., Ragnarsson, U., Alexandrova, M., Strbak, V., Tonon, M. C., Vaudry, H. (1985) Experientia, 41, 1576.

15. Sherman, D. B., Spatola, A. F., Wire, W. S., Burks, T. F., Nguyen, T. M.D., Schiller, P. W. (1989) Biochem. Biophys. Res. Commun., 162, 1126.

16. DiMaio, J., Nguyen, T. M.-D., Lemieux, C., Schiller, P. W. (1982) J. Med. Chem., 25, 1432.

17. Lankiewicz, L., Sherman, D. B., Spatola, A. F. (1989) in Peptides: Chemistry, Structure and Biology, Proceedings of the Eleventh American Peptide Symposium (Rivier, J. E. and Marshall, G. R., eds.), p. 976, ESCOM, Leiden.

18. Lankiewicz, L., Spatola, A. F., Bowers, C. Y., Reynolds, G. A. (1990) in Peptides 1990, Proceedings of the Twenty-First European Peptide Symposium (Giralt, E. and Andreu, D., eds.), p. 393, ESCOM, Leiden.

19. Taylor, R. L., Burt, D. R. (1981) Neuroendocrinology, 32, 310.

20. Cheng, Y., Prusoff, W. H. (1973) Biochem. Pharmacol., 22, 3099.

21. Griffiths, E. C., McDermott, J. R., Visser, T. J. (1983) in Thyrotropin Releasing Hormone (Griffiths, E. C. and Bennett, G. W., eds.), pp. 85-95, Raven Press, New York.

22. Vonhof, S., Paakkari, I., Feuerstein, G., Cohen, L. A., Labroo, V. M. (1989) European J. Pharmacol., 164, 77.

23. Sirén, A. L. (1986) Neuropeptides, 8, 63.

24. Labroo, V. M., Cohen, L. A., Lozovsky, D., Sirén, A.-L., Feuerstein, G. (1987) Neuropeptides, 10, 29.

25. Vonhof, S., Feuerstein, G., Cohen, L. A., Labroo, V., European J. Pharmacol., 180, 1.

26. Bennett, H. P. J., McMartin, C. (1979) Pharmacological Reviews, 30, 247. 